\title{
Marine bacterial communities in the upper gulf of Thailand assessed by Illumina next- generation sequencing platform
}

\author{
Pongrawee Nimnoi ${ }^{1 \dagger}$ and Neelawan Pongsilp ${ }^{2^{*}+}$ (B)
}

\begin{abstract}
Background: The total bacterial community plays an important role in aquatic ecosystems. In this study, bacterial communities and diversity along the shores of the Upper Gulf of Thailand were first characterized. The association between bacterial communities and types of land use was also evaluated.

Results: The bacterial communities and diversity of seawater in the Upper Gulf of Thailand, with regard to types of land use, were first revealed by using Illumina next-generation sequencing. A total of 4953 OTUs were observed from all samples in which 554 OTUs were common. The bacterial communities in sampling sites were significantly different from each other. The run-off water from three types of land use significantly affected the community richness and diversity of marine bacteria. Aquaculture sites contained the highest levels of community richness and diversity, followed by mangrove forests and tourist sites. Seawater physicochemical parameters including salinity, turbidity, TSS, total $\mathrm{N}$, and $\mathrm{BOD}_{5}$, were significantly different when grouped by land use. The bacterial communities were mainly determined by salinity, total $\mathrm{N}$, and total $\mathrm{P}$. The species richness estimators and OTUs were positively correlated with turbidity. The top ten most abundant phyla and genera as well as the distribution of bacterial classes were characterized. The Proteobacteria constituted the largest proportions in all sampling sites, ranging between 67.31 and 78.80\%. The numbers of the Marinobacterium, Neptuniibacter, Synechococcus, Candidatus Thiobios, hgcl clade (Actinobacteria), and Candidatus Pelagibacter were significantly different when grouped by land use.

Conclusions: Type of land use significantly affected bacterial communities and diversity along the Upper Gulf of Thailand. Turbidity was the most influential parameter affecting the variation in bacterial community composition. Salinity, total N, and P were the ones of the important factors that shaped the bacterial communities. In addition, the variations of bacterial communities from site-to-site were greater than within-site. The Proteobacteria, Bacteroidetes, Actinobacteria, Cyanobacteria, Verrucomicrobia, Euryarchaeota, Planctomycetes, Firmicutes, Deep Sea DHVEG-6, and Marinimicrobia were the most and common phyla distributed across the Upper Gulf of Thailand.
\end{abstract}

Keywords: The Gulf of Thailand, Bacterial community, Illumina next-generation sequencing, Land use, Marine microbiota

\section{Background}

The Gulf of Thailand locates from $6^{\circ} \mathrm{N}$ to $13^{\circ} 30^{\prime} \mathrm{N}$ latitude and $99^{\circ} \mathrm{E}$ to $104^{\circ} \mathrm{E}$ longitude. It is a semi-enclosed tropical marine embayment which is surrounded by the land masses of Thailand, Cambodia, Vietnam, and Malaysia [1].

\footnotetext{
* Correspondence: pongsilp_n@su.ac.th

${ }^{\dagger}$ Pongrawee Nimnoi Neelawan Pongsilp: Both authors contributed equally to this article and share first authorship.

${ }^{2}$ Department of Microbiology, Faculty of Science, Silpakorn University,

Nakhon Pathom, Thailand

Full list of author information is available at the end of the article
}

It constitutes a part of the South China Sea and is characterized as an estuary of drowned river valley. It is divided into the Upper and Lower Gulf based on its geography. The Upper Gulf has an inverted U-shape with the area of approximately 10,000 square $\mathrm{km}$ and the deepest point of approximately $40 \mathrm{~m}$. The Upper Gulf is the catchment basin of four large rivers including the Chaopraya River, the Thachin River, the Bangpakong River, and the Maeklong River [2]. The coastal areas of the Upper Gulf are composed of agricultural areas, aquaculture areas, mangrove forests, swamp forests, forests, industrial areas, and 
urban areas [3], therefore it is of importance for natural resources, environment, and public health. Coastal seawater of the Upper Gulf of Thailand is utilized for environmental preservation, coral conservation, conservation of natural resources, aquaculture, fishery, water sport, recreation, transportation, and industry. Despite its importance, the total microbiota has not been investigated. The total bacterial community, which plays an important role in aquatic ecosystems, should be considered as a rigorous criterion for water quality to promote sustainable development. It is important to evaluate changes in the microbial community structure in aquatic systems because the microbial community is the foundation of biogeochemical cycles and pollutant biodegradation [4]. In particular, there is growing interest in the role of marine microorganisms that inhabit extreme habitats in biogeochemical processes, pollution, and health. Thermophiles, halophiles, alkalophiles, psychrophiles, piezophiles, and polyextremophiles have been isolated from marine environments. Marine environments represent the richest source of new genes, enzymes, and natural products [5]. Marine bacterial community structure is affected by several factors such as inorganic nutrient concentration [6], $\mathrm{N}[7,8], \mathrm{P}$ [7], change in season, adjacent habitat [9], depth $[8,10]$, oxygen [10], protist predation pressure [11], salinity $[7,8,12]$, dominance of algae, particulate organic carbon, $\mathrm{Si}(\mathrm{OH})_{4}$ [8], human disturbance, and sand mining activity [13].

To explore the total bacterial community in the environment, high-throughput next-generation sequencing (NGS) technology of the taxonomically informative 16S rRNA gene provides the most powerful approach because it enables the classification of individual reads to specific taxa [14]. The contemporary advances in NGS have not only enabled finer characterization of bacterial genomes but also provided deeper taxonomic identification of complex microbiomes [15]. NGS approach was employed to survey microbial communities from several marine environments such as the Gulf of Mexico [16, 17], the Georgetown Coast, Malaysia [18], Malipo Beach, South Korea [19], the Canadian Arctic archipelago [8], and the South Sea, Korea [13].

In this study, we investigated 1) the marine bacterial communities at nine sites along the shores of the Upper Gulf of Thailand by using Illumina NGS of the V4 variable region of $16 \mathrm{~S}$ rRNA gene; 2) the association between bacterial community structures and three types of land use including mangrove forests, tourist sites, and aquaculture sites; 3) effect of seawater physicochemical parameters on the abundance of specific taxa; and 4) the correlation between seawater physicochemical parameters and types of land use.

\section{Results}

Seawater physicochemical parameters

Nine sampling sites in seven provinces along the shores of the Upper Gulf of Thailand, over a distance of approximately $769.97 \mathrm{~km}$, are shown in Table 1 and Fig. 1 . Seawater parameters including temperature, $\mathrm{pH}$, salinity, turbidity, total suspended solid (TSS), total N, total P, and five-day biochemical oxygen demand $\left(\mathrm{BOD}_{5}\right)$ at nine sampling sites are shown in Table 2. Temperatures and $\mathrm{pH}$ values of seawater samples among nine sampling sites ranged from $27^{\circ} \mathrm{C}$ to $31^{\circ} \mathrm{C}$ and 6.7 to 7.5 , respectively. Salinity (presented as $\% \mathrm{NaCl}$ ) of all sites were 4.0, except sites F (aquaculture site at Donhoylhod) and G (aquaculture site at Bangtaboon Bay) that were 3.0 and 1.0, respectively. Turbidity, TSS, total $\mathrm{N}$, and total $\mathrm{P}$ of all sites ranged from $2.32 \pm 0.03$ to $102.00 \pm 1.00$ nephelometric turbidity units (NTUs), $22.00 \pm 0.80$ to $177.66 \pm 5.50 \mathrm{mg} / \mathrm{l}, 0.13 \pm 0.00$ to $1.30 \pm 0.13 \mathrm{mg} / \mathrm{l}$, and $0.03 \pm 0.00$ to $0.10 \pm 0.01 \mathrm{mg} / \mathrm{l}$, respectively. Site G (aquaculture site at Bangtaboon Bay) had the highest turbidity, TSS, total N, and total $\mathrm{P}$ which were significantly different from those of other sites. On the contrary, site A (mangrove forest at Black Sand Beach) was the only site that had significantly lowest turbidity. Sites A (mangrove forest at Black Sand Beach), B (mangrove forest at Kungkrabaen Bay), C (tourist site at Suanson Beach), and I (tourist site at Wanakorn Beach) shared the lowest rank of TSS which was significantly different from that of other sites. Site C (tourist site at Suanson Beach) contained the lowest amount of total $\mathrm{N}$ which was not significantly from that of site D (tourist site at Pattaya Beach). Sites A (mangrove forest at Black Sand Beach) and E (aquaculture site at Angsila old market) contained the lowest amounts of total $\mathrm{P}$ which were not significantly different from those of sites $\mathrm{B}$ and $\mathrm{C} . \mathrm{BOD}_{5}$ values of all sites ranged between $0.90 \pm$ 0.00 and $3.76 \pm 0.23 \mathrm{mg} / \mathrm{l}$. Site B (mangrove forest at Kungkrabaen Bay) had the highest $\mathrm{BOD}_{5}$ value, differing significantly from that of other sites. On the contrary, sites F (aquaculture site at Donhoylhod) and I (tourist site at Wanakorn Beach) had the lowest $\mathrm{BOD}_{5}$ values.

In this study, the results in Table 3 show that air temperature, $\mathrm{pH}$, and total $\mathrm{P}$ were not significantly different when grouped by land use $(P=0.27,0.35$, and $0.13)$. On the contrary, seawater temperature, $\% \mathrm{NaCl}$, turbidity, TSS, total $\mathrm{N}$, and $\mathrm{BOD}_{5}$ were significantly different when grouped by land use $(P=0.00,0.01,0.00$, $0.00,0.00$, and 0.01 ). Turbidity, TSS, and total $\mathrm{N}$ of aquaculture sites were highest, differing significantly from those of other types of land use. $\mathrm{BOD}_{5}$ value of mangrove forests was highest, differing significantly from that of tourist sites. Aquaculture sites had the lowest values of $\% \mathrm{NaCl}$ that were significantly different from those of other types of land use.

\section{Sequence analyses and diversity indices}

A total of 2,478,774 raw reads were obtained from 27 DNA samples (3 replicates/sampling site). After tag merge and quality control, a total of 2,425,463 clean tags (97.85\% of raw reads) were obtained. After that, 
Table 1 Site locations, sampling dates and land use

\begin{tabular}{llllllll}
\hline Site & Sampling date & Place & District, Province & Latitude & Longitude & Distance (km) & Land use \\
\hline A & $11 / 10 / 2018$ & Black Sand Beach & Laemngop, Trat & $12.169 \mathrm{~N}$ & $102.406 \mathrm{E}$ & 0.00 & Mangrove forest \\
B & $11 / 10 / 2018$ & Kungkrabaen Bay & Thamai, Chanthaburi & $12.573 \mathrm{~N}$ & $101.902 \mathrm{E}$ & 123.57 & Mangrove forest \\
C & $11 / 10 / 2018$ & Suanson Beach & Mueang, Rayong & $12.458 \mathrm{~N}$ & $101.473 \mathrm{E}$ & 190.51 & Tourist site \\
D & $11 / 10 / 2018$ & Pattaya Beach & Banglamoong, Chonburi & $12.936 \mathrm{~N}$ & $100.883 \mathrm{E}$ & 326.22 & Tourist site \\
E & $11 / 10 / 2018$ & Angsila old market & Mueang, Chonburi & $13.341 \mathrm{~N}$ & $100.926 \mathrm{E}$ & 388.60 & Aquaculture site \\
F & $12 / 01 / 2018$ & Donhoylhod & Meung, Samutsongkhram & $13.361 \mathrm{~N}$ & $100.022 \mathrm{E}$ & 527.64 & Aquaculture site \\
G & $12 / 01 / 2018$ & Bangtaboon Bay & Banlaem, Phetchaburi & $13.264 \mathrm{~N}$ & $99.945 \mathrm{E}$ & 548.77 & Aquaculture site \\
H & $12 / 01 / 2018$ & Pranburi forest park & Pranburi, Prachuapkhirikhan & $12.412 \mathrm{~N}$ & $99.981 \mathrm{E}$ & 659.23 & Mangrove forest \\
I & $12 / 01 / 2018$ & Wanakorn Beach & Thubsakae, Prachuapkhirikhan & $11.635 \mathrm{~N}$ & $99.703 \mathrm{E}$ & 769.97 & Tourist site \\
\hline
\end{tabular}

potential chimera tags were removed with the UCHIME algorithm, resulting in a total of 2,177,667 taxon tags. The tags with $\geq 97 \%$ similarity were grouped into the same operational taxonomic units (OTUs). A total of 4953 OTUs were observed from all samples, with a mean Good's coverage of $99.00 \pm 0.00 \%$. ACE (abundance-based coverage estimator) and Chao1 that represent richness as well as Shannon-Weaver and Simpson that indicate diversity were analyzed (Table 2). When measured by ACE and Chao1, samples collected were significantly different when grouped by land use $(P=$ 0.02 and 0.01 ) (Table 4). Aquaculture sites contained the highest community richness, followed by mangrove forests and tourist sites, respectively. The indices of community diversity assessed by Shannon and Simpson also exhibited that samples collected were significantly different when grouped by land use $(P=0.00$ and 0.00$)$. The bacterial community diversity of aquaculture sites was significantly highest, followed by mangrove forests and tourist sites, respectively (Table 4).

The bacterial richness (ACE and Chao1) of site F (aquaculture site at Donhoylhod) was highest, followed by sites A (mangrove forest at Black Sand Beach) and E (aquaculture site at Angsila old market), respectively. The bacterial richness of site I (tourist site at Wanakorn Beach) was lowest. Higher Shannon-Weaver and Simpson indices

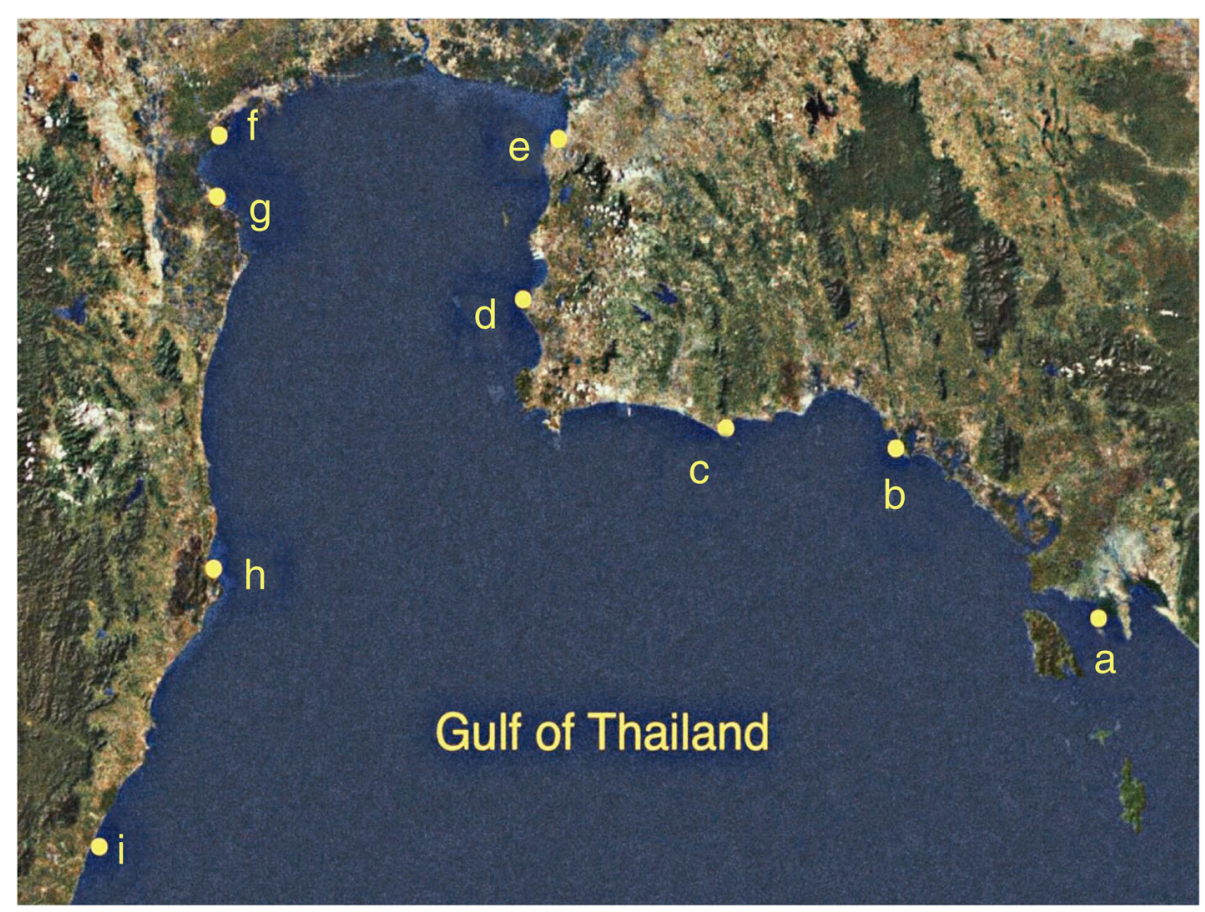

Fig. 1 Map of sampling sites along the shores of the Upper Gulf of ThailandRetrieved from a development of drought risk analysis platform of Kasetsart University Research and Development Institute (KURDI) (http://csrs.ku.ac.th). Site a, mangrove forest at Black Sand Beach; b, mangrove forest at Kungkrabaen Bay; $\mathbf{c}$, tourist site at Suanson Beach; $\mathbf{d}$, tourist site at Pattaya Beach; $\mathbf{e}$, aquaculture site at Angsila old market; $\mathbf{f}$, aquaculture site at Donhoylhod; $\mathbf{g}$, aquaculture site at Bangtaboon Bay; $\mathbf{h}$, mangrove forest at Pranburi forest park; i, tourist site at Wanakorn Beach 
Table 2 Seawater parameters and alpha diversity indices of bacterial communities and richness among all samples collected and consolidated by site

\begin{tabular}{|c|c|c|c|c|c|c|c|c|c|c|c|c|c|c|}
\hline \multirow[t]{2}{*}{ Site } & \multirow{2}{*}{$\begin{array}{l}\text { Air temp } \\
\left({ }^{\circ} \mathrm{C}\right)\end{array}$} & \multicolumn{8}{|c|}{ Seawater parameter data } & \multicolumn{5}{|c|}{ Bacterial diversity indices $^{a}$} \\
\hline & & $\begin{array}{l}\text { Seawater } \\
\text { temp. } \\
\left({ }^{\circ} \mathrm{C}\right)\end{array}$ & $\mathrm{pH}$ & $\begin{array}{l}\% \\
\mathrm{NaCl}\end{array}$ & $\begin{array}{l}\text { Turbidity } \\
\text { (NTU) }^{\mathrm{a}}\end{array}$ & $\begin{array}{l}\text { TSS } \\
(\mathrm{mg} /)^{\mathrm{a}}\end{array}$ & $\begin{array}{l}\text { Total N } \\
(\mathrm{mg} /)^{\mathrm{a}}\end{array}$ & $\begin{array}{l}\text { Total P } \\
(\mathrm{mg} /)^{\mathrm{a}}\end{array}$ & $\begin{array}{l}\mathrm{BOD}_{5} \\
(\mathrm{mg} /)^{\mathrm{a}}\end{array}$ & OTUs & Chao1 & ACE & Shannon & Simpson \\
\hline $\bar{A}$ & 28 & 29 & 7.0 & 4.0 & $\begin{array}{l}10.96 \pm \\
0.25 d^{b}\end{array}$ & $\begin{array}{l}22.00 \pm \\
0.80 a\end{array}$ & $\begin{array}{l}0.42 \pm \\
0.06 \mathrm{bc}\end{array}$ & $\begin{array}{l}0.03 \pm \\
0.01 a\end{array}$ & $\begin{array}{l}1.90 \pm \\
0.00 \mathrm{de}\end{array}$ & 5854 & $\begin{array}{l}1940.77 \pm \\
69.19 c\end{array}$ & $\begin{array}{l}2022.59 \pm \\
68.24 c\end{array}$ & $\begin{array}{l}7.33 \pm \\
0.06 \mathrm{bc}\end{array}$ & $\begin{array}{l}0.97 \pm \\
0.00 \mathrm{~b}\end{array}$ \\
\hline B & 25 & 28 & 7.2 & 4.0 & $\begin{array}{l}12.60 \pm \\
0.26 \mathrm{e}\end{array}$ & $\begin{array}{l}26.66 \pm \\
1.00 a\end{array}$ & $\begin{array}{l}0.42 \pm \\
0.06 \mathrm{bc}\end{array}$ & $\begin{array}{l}0.04 \pm \\
0.01 \mathrm{ab}\end{array}$ & $\begin{array}{l}3.76 \pm \\
0.23 f\end{array}$ & 4968 & $\begin{array}{l}1631.89 \pm \\
41.68 \mathrm{ab}\end{array}$ & $\begin{array}{l}1675.02 \pm \\
47.72 \mathrm{ab}\end{array}$ & $\begin{array}{l}7.23 \pm \\
0.04 b\end{array}$ & $\begin{array}{l}0.97 \pm \\
0.00 \mathrm{~b}\end{array}$ \\
\hline C & 30 & 29 & 7.1 & 4.0 & $\begin{array}{l}10.80 \pm \\
0.17 d\end{array}$ & $\begin{array}{l}27.53 \pm \\
0.30 a\end{array}$ & $\begin{array}{l}0.13 \pm \\
0.00 a\end{array}$ & $\begin{array}{l}0.04 \pm \\
0.00 \mathrm{ab}\end{array}$ & $\begin{array}{l}1.40 \pm \\
0.10 \mathrm{bc}\end{array}$ & 4829 & $\begin{array}{l}1588.03 \pm \\
25.36 a b\end{array}$ & $\begin{array}{l}1649.36 \pm \\
37.50 \mathrm{ab}\end{array}$ & $\begin{array}{l}7.46 \pm \\
0.06 \mathrm{~cd}\end{array}$ & $\begin{array}{l}0.97 \pm \\
0.00 \mathrm{~b}\end{array}$ \\
\hline D & 26 & 31 & 7.4 & 4.0 & $\begin{array}{l}24.80 \pm \\
0.30 f\end{array}$ & $\begin{array}{l}65.60 \pm \\
1.74 c\end{array}$ & $\begin{array}{l}0.21 \pm \\
0.06 \mathrm{ab}\end{array}$ & $\begin{array}{l}0.06 \pm \\
0.00 \mathrm{bc}\end{array}$ & $\begin{array}{l}1.43 \pm \\
0.05 \mathrm{bc}\end{array}$ & 5023 & $\begin{array}{l}1630.61 \pm \\
7.82 \mathrm{ab}\end{array}$ & $\begin{array}{l}1708.45 \pm \\
24.40 \mathrm{ab}\end{array}$ & $\begin{array}{l}6.91 \pm \\
0.05 a\end{array}$ & $\begin{array}{l}0.96 \pm \\
0.00 a\end{array}$ \\
\hline E & 27 & 30 & 7.4 & 4.0 & $\begin{array}{l}3.76 \pm \\
0.20 \mathrm{~b}\end{array}$ & $\begin{array}{l}43.86 \pm \\
1.00 \mathrm{~b}\end{array}$ & $\begin{array}{l}0.54 \pm \\
0.07 \mathrm{~cd}\end{array}$ & $\begin{array}{l}0.03 \pm \\
0.00 a\end{array}$ & $\begin{array}{l}1.66 \pm \\
0.05 c d\end{array}$ & 5284 & $\begin{array}{l}1813.01 \pm \\
209.44 b c\end{array}$ & $\begin{array}{l}1851.33 \pm \\
195.23 b c\end{array}$ & $\begin{array}{l}7.40 \pm \\
0.01 c\end{array}$ & $\begin{array}{l}0.97 \pm \\
0.00 \mathrm{~b}\end{array}$ \\
\hline $\mathrm{F}$ & 31 & 27 & 6.7 & 3.0 & $\begin{array}{l}91.33 \pm \\
0.57 \mathrm{~g}\end{array}$ & $\begin{array}{l}165.33 \pm \\
5.03 \mathrm{~d}\end{array}$ & $\begin{array}{l}0.67 \pm \\
0.09 d\end{array}$ & $\begin{array}{l}0.07 \pm \\
0.00 c\end{array}$ & $\begin{array}{l}1.16 \pm \\
0.11 \mathrm{ab}\end{array}$ & 6016 & $\begin{array}{l}1946.48 \pm \\
177.06 \mathrm{c}\end{array}$ & $\begin{array}{l}2037.32 \pm \\
218.82 c\end{array}$ & $\begin{array}{l}7.60 \pm \\
0.07 d\end{array}$ & $\begin{array}{l}0.98 \pm \\
0.00 c\end{array}$ \\
\hline G & 26 & 30 & 7.5 & 1.0 & $\begin{array}{l}102.00 \pm \\
1.00 \mathrm{~h}\end{array}$ & $\begin{array}{l}177.66 \pm \\
5.50 \mathrm{e}\end{array}$ & $\begin{array}{l}1.30 \pm \\
0.13 e\end{array}$ & $\begin{array}{l}0.10 \pm \\
0.01 d\end{array}$ & $\begin{array}{l}2.03 \pm \\
0.05 e\end{array}$ & 5000 & $\begin{array}{l}1622.41 \pm \\
66.51 \mathrm{ab}\end{array}$ & $\begin{array}{l}1680.02 \pm \\
88.45 \mathrm{ab}\end{array}$ & $\begin{array}{l}7.84 \pm \\
0.00 \mathrm{e}\end{array}$ & $\begin{array}{l}0.98 \pm \\
0.00 c\end{array}$ \\
\hline $\mathrm{H}$ & 29 & 28 & 6.9 & 4.0 & $\begin{array}{l}7.86 \pm \\
0.15 c\end{array}$ & $\begin{array}{l}36.66 \pm \\
1.52 b\end{array}$ & $\begin{array}{l}0.42 \pm \\
0.06 \mathrm{bc}\end{array}$ & $\begin{array}{l}0.06 \pm \\
0.00 c\end{array}$ & $\begin{array}{l}1.26 \pm \\
0.11 \mathrm{bc}\end{array}$ & 4696 & $\begin{array}{l}1545.04 \pm \\
16.43 a b\end{array}$ & $\begin{array}{l}1608.19 \pm \\
31.63 a b\end{array}$ & $\begin{array}{l}7.00 \pm \\
0.06 a\end{array}$ & $\begin{array}{l}0.97 \pm \\
0.00 b\end{array}$ \\
\hline & 31 & 30 & 7.0 & 4.0 & $\begin{array}{l}2.32 \pm \\
0.03 a\end{array}$ & $\begin{array}{l}28.33 \pm \\
0.57 a\end{array}$ & $\begin{array}{l}0.38 \pm \\
0.00 \mathrm{bc}\end{array}$ & $\begin{array}{l}0.07 \pm \\
0.01 c\end{array}$ & $\begin{array}{l}0.90 \pm \\
0.00 a\end{array}$ & 4246 & $\begin{array}{l}1383.67 \pm \\
77.21 a\end{array}$ & $\begin{array}{l}1443.29 \pm \\
63.56 a\end{array}$ & $\begin{array}{l}6.92 \pm \\
0.06 a\end{array}$ & $\begin{array}{l}0.97 \pm \\
0.00 b\end{array}$ \\
\hline
\end{tabular}

All sites were sampled in triplicate $(n=3)$

a Values are the means from three samplings \pm standard deviations

${ }^{b}$ Values with the same letters within a column are not significantly different according to Tukey's test

indicate greater bacterial diversity. The highest values of both indices were found in site G (aquaculture site at Bangtaboon Bay), followed by sites $F$ (aquaculture site at Donhoylhod) and C (tourist site at Suanson Beach), respectively. The lowest values were found in site D (tourist site at Pattaya Beach).

\section{Illumina NGS and bacterial community structure}

Rarefaction analysis was used to standardize and compare taxon richness among samples and to identify whether the samples were randomly selected. According to the rarefaction curves of samples (Additional file 1: Figure S1), all of the samples were randomly collected. Moreover, aquaculture sites exhibited the steepest rarefaction curves, indicating the highest taxon richness, while tourist sites exhibited the most gradual curves. As shown in a Flower display (Additional file 2: Figure S2), 554 OTUs were common in all sampling sites. Site G (aquaculture site at Bangtaboon Bay) had the highest unique OTUs (259 OTUs), followed by sites A (mangrove forest at Black Sand Beach) and F (aquaculture site at Donhoylhod), respectively, whereas sites $\mathrm{H}$ (mangrove forest at Pranburi forest park) and I (tourist site at Wanakorn Beach) had the equally lowest unique OTUs (58 OTUs).

The top ten most abundant phyla among nine sampling sites were in different patterns, as depicted in Fig. 2.

Table 3 Physicochemical parameters analyzed based on type of land use

\begin{tabular}{|c|c|c|c|c|c|c|c|c|c|}
\hline \multirow[t]{2}{*}{ Type of land use } & \multirow{2}{*}{$\begin{array}{l}\text { Air temp. } \\
\left({ }^{\circ} \mathrm{C}\right)^{*}\end{array}$} & \multicolumn{8}{|c|}{ Seawater parameter data* } \\
\hline & & $\begin{array}{l}\text { Seawater temp. } \\
\left({ }^{\circ} \mathrm{C}\right)\end{array}$ & $\mathrm{pH}$ & $\% \mathrm{NaCl}$ & $\begin{array}{l}\text { Turbidity } \\
\text { (NTU) }\end{array}$ & $\begin{array}{l}\mathrm{TSS} \\
(\mathrm{mg} / \mathrm{l})\end{array}$ & $\begin{array}{l}\text { Total N } \\
(\mathrm{mg} / \mathrm{l})\end{array}$ & $\begin{array}{l}\text { Total P } \\
(\mathrm{mg} / \mathrm{l})\end{array}$ & $\begin{array}{l}\mathrm{BOD}_{5} \\
(\mathrm{mg} / \mathrm{l})\end{array}$ \\
\hline Mangrove forests & $\begin{array}{l}27.33 \pm \\
1.80 a^{* *}\end{array}$ & $28.33 \pm 0.50 a$ & $\begin{array}{l}7.03 \pm \\
0.13 a\end{array}$ & $\begin{array}{l}4.00 \pm \\
0.00 b\end{array}$ & $10.47 \pm 2.09 a$ & $28.44 \pm 6.56 a$ & $\begin{array}{l}0.42 \pm \\
0.06 a\end{array}$ & $\begin{array}{l}0.04 \pm \\
0.01 a\end{array}$ & $2.31 \pm 1.13 b$ \\
\hline Tourist sites & $29.00 \pm 2.29 a$ & $30.00 \pm 0.86 b$ & $\begin{array}{l}7.16 \pm \\
0.18 a\end{array}$ & $\begin{array}{l}4.00 \pm \\
0.00 b\end{array}$ & $12.64 \pm 9.83 a$ & $40.48 \pm 18.85 a$ & $\begin{array}{l}0.24 \pm \\
0.11 a\end{array}$ & $\begin{array}{l}0.05 \pm \\
0.01 a\end{array}$ & $1.24 \pm 0.26 a$ \\
\hline Aquaculture sites & $28.00 \pm 2.29 a$ & $29.00 \pm 1.50 a b$ & $\begin{array}{l}7.20 \pm \\
0.37 a\end{array}$ & $\begin{array}{l}2.66 \pm \\
1.32 \mathrm{a}\end{array}$ & $\begin{array}{l}65.70 \pm \\
46.68 b\end{array}$ & $\begin{array}{l}128.95 \pm \\
64.50 b\end{array}$ & $\begin{array}{l}0.84 \pm \\
0.36 b\end{array}$ & $\begin{array}{l}0.07 \pm \\
0.03 a\end{array}$ & $\begin{array}{l}1.62 \pm \\
0.38 \mathrm{ab}\end{array}$ \\
\hline $\begin{array}{l}p \text {-value } e^{* * *} \\
\text { (between groups) }\end{array}$ & 0.27 & 0.00 & 0.35 & 0.01 & 0.00 & 0.00 & 0.00 & 0.13 & 0.01 \\
\hline
\end{tabular}

*Values are the means of three samplings from each location \pm standard deviations

** Values with the same letters within a column are not significantly different according to Tukey's test

*** $p$-values $<0.05$ are considered significant 
Table 4 Community richness and community diversity indices analyzed based on type of land use

\begin{tabular}{|c|c|c|c|c|}
\hline \multirow[t]{2}{*}{ Type of land use } & \multicolumn{2}{|l|}{ Community richness } & \multicolumn{2}{|c|}{ Community diversity } \\
\hline & Chao1 & ACE & Shannon & Simpson \\
\hline Mangrove forests & $1705.90 \pm 184.77 a b^{* *}$ & $1768.60 \pm 197.76 \mathrm{ab}$ & $7.19 \pm 0.15 a$ & $0.97 \pm 0.00 a$ \\
\hline Tourist site & $1534.10 \pm 121.39 a$ & $1600.37 \pm 126.66 a$ & $7.10 \pm 0.27 a$ & $0.97 \pm 0.00 a$ \\
\hline Aquaculture site & $1739.97 \pm 199.51 b$ & $1856.22 \pm 217.73 b$ & $7.61 \pm 0.19 b$ & $0.98 \pm 0.00 b$ \\
\hline$p$-value*** (between groups) & 0.01 & 0.02 & 0.00 & 0.01 \\
\hline
\end{tabular}

*Values are the means of three samplings from each location \pm standard deviations

**Values with the same letters within a column are not significantly different according to Tukey's test

${ }^{* * *} p$-values $<0.05$ are considered significant

The Proteobacteria were most abundant in all sampling sites, ranging between 67.31 and $78.80 \%$, followed by the Bacteroidetes (10.38-17.68\%), Cyanobacteria (2.6415.16\%), Actinobacteria (1.41-11.68\%), Verrucomicrobia (0.30-1.89\%), Euryarchaeota (0.24-1.47\%), Planctomycetes (0.19-1.04\%), Marinimicrobia (0.05-0.92\%), Firmicutes (0.02-0.41\%), Deep Sea Hydrothermal Vent Group 6 (DHVEG-6; 0.01-0.33\%), and others (1.09-1.25\%). The distribution of bacterial classes in each sampling site is shown in Fig. 3. The colors in a heat map chart indicate the relative abundance of the community. The colors which vary from deep blue to dark brown represent low- to high-levels of the relative abundance. The most abundant classes in each site are represented as dark-brown squares in a heat map chart. In site A (mangrove forest at Black Sand Beach), the Holophagae, Anaerolineae, and Chloroplast were more abundant than others. The Bacilli, OM190, Sphingobacteriia, Acidimicrobiia, and Verrucomicrobiae were the predominant classes in site B (mangrove forest at Kungkrabaen Bay).
The greatest abundance of the JdFBHP3 was found in site $\mathrm{C}$ (tourist site at Suanson Beach). The Mollicutes, $\gamma$-Proteobacteria, and Opitutae were the predominant classes in site D (tourist site at Pattaya Beach). Site E (aquaculture site at Angsila old market) had the most abundance of the $\gamma$-Proteobacteria. Site F (aquaculture site at Donhoylhod) harbored the high numbers of the Bacteroidia, Epsilonproteobacteria, Nitriliruptoria, and Clostridia. Site G (aquaculture site at Bangtaboon Bay) had several mostabundant classes such as the Chloroflexia, Spartobacteria, Thermoleophilia, Chlorobia, and Planctomycetacia. The unidentified Marinimicrobia and unidentified Cyanobacteria were the most abundant classes in sites $\mathrm{H}$ (mangrove forest at Pranburi forest park) and I (tourist site at Wanakorn Beach), respectively.

The top ten most abundant genera present in each sampling site are shown in an Additional file 3: Table S1). The highest numbers of the genus Marinobacterium was presented in four sites including $\mathrm{E}$ (aquaculture site at Angsila old market), $\mathrm{H}$ (mangrove forest at Pranburi

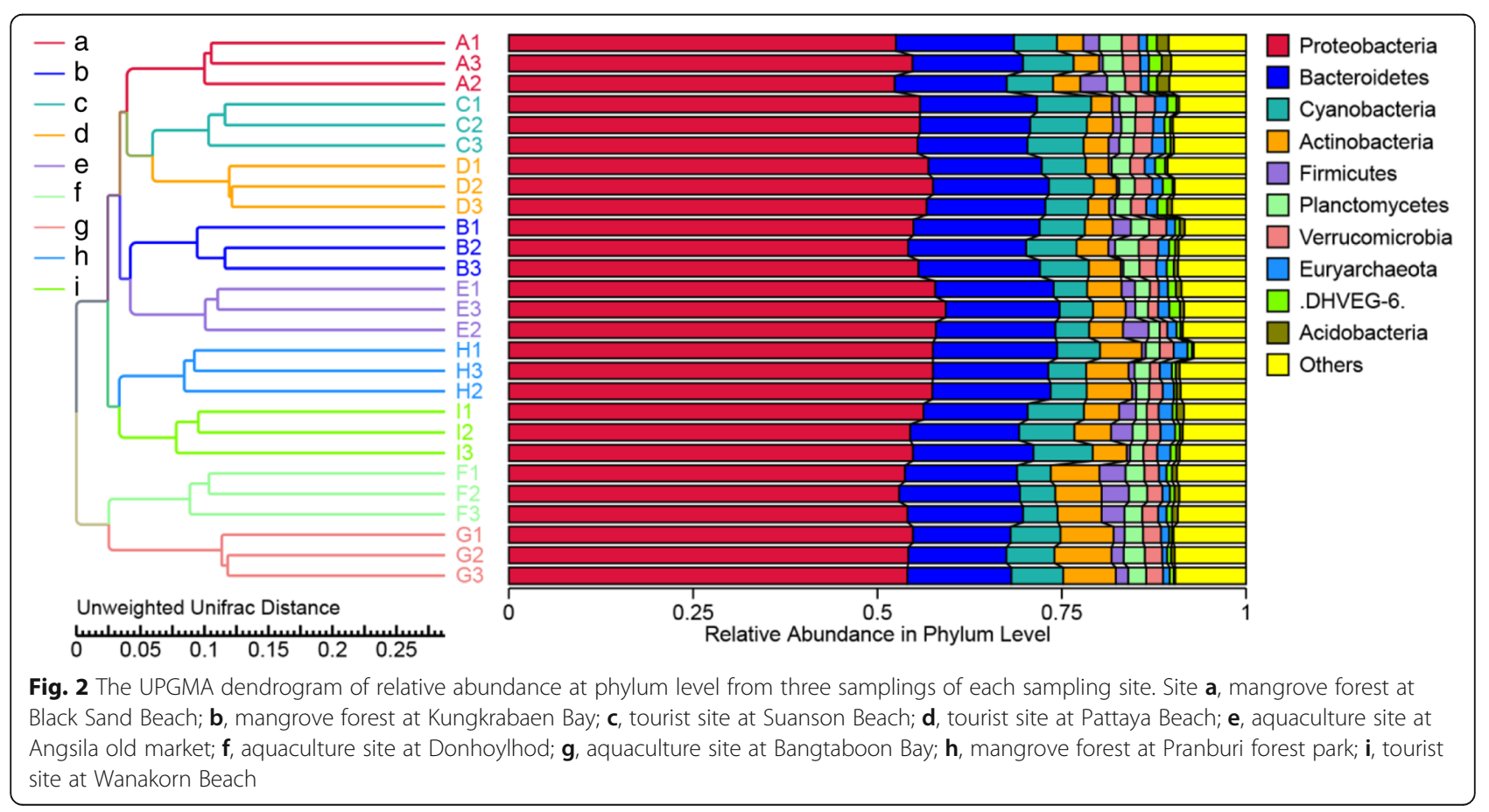




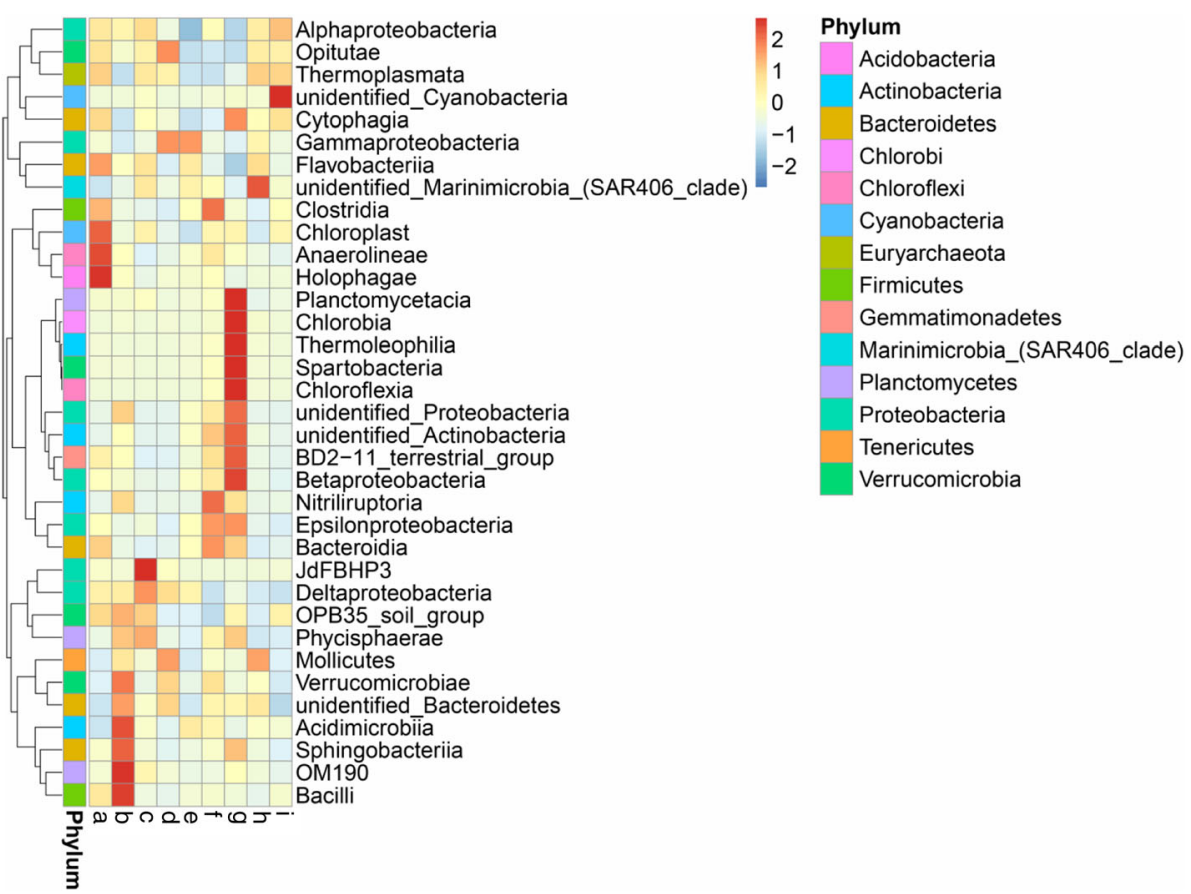

Fig. 3 Heat map analysis of class distribution in each sampling site. Site $\mathbf{a}$, mangrove forest at Black Sand Beach; $\mathbf{b}$, mangrove forest at Kungkrabaen Bay; $\mathbf{c}$, tourist site at Suanson Beach; $\mathbf{d}$, tourist site at Pattaya Beach; e, aquaculture site at Angsila old market; $\mathbf{f}$, aquaculture site at Donhoylhod; $\mathbf{g}$, aquaculture site at Bangtaboon Bay; $\mathbf{h}$, mangrove forest at Pranburi forest park; $\mathbf{i}$, tourist site at Wanakorn Beach

forest park), G (aquaculture site at Bangtaboon Bay), and A (mangrove forest at Black Sand Beach), which were not significantly different from each other. Site D (tourist site at Pattaya Beach) had the greatest number of the Neptuniibacter, differing significantly from that of other sites. Site I (tourist site at Wanakorn Beach) had the highest abundances of the Synechococcus and Candidatus Pelagibacter which were significantly different from those of other sites. The numbers of the Candidatus Actinomarina, Candidatus Thiobios, Vibrio, and Marinomonas were significantly highest in sites B (mangrove forest at Kungkrabaen Bay), G (aquaculture site at Bangtaboon Bay), C (tourist site at Suanson Beach), and E (aquaculture site at Angsila old market), respectively.

The ordination of samples by principal coordinate analysis (PCoA) shown in Fig. 4 revealed a significant clustering of samples by sampling site, and this separation was supported by analysis of molecular variance (AMOVA) $(P<0.001)$. Moreover, the variations in community composition among groups and within groups were evaluated by analysis of similarity (ANOSIM) and multi-response permutation procedure (MRPP). The results of both methods indicate that there were significant differences when comparing microbiota by sampling site $(P<0.05)$, and the variations of inter-group were larger than those of inner-group $(r=1)$. The unweighted-pair group method with arithmetic mean (UPGMA) dendrogram of the relative abundance at the phylum level depicted in Fig. 2 was divided into four clusters. The first cluster that contained sites A (mangrove forest at Black Sand Beach), C (tourist site at Suanson Beach), and D (tourist site at Pattaya Beach), was closer to the second cluster that contained sites B (mangrove forest at Kungkrabaen Bay) and E (aquaculture site at Angsila old market). The third cluster was composed of sites $\mathrm{H}$ (mangrove forest at Pranburi forest park) and I (tourist site at Wanakorn Beach). The last cluster containing sites F (aquaculture site at Donhoylhod) and G (aquaculture site at Bangtaboon Bay) was more separated from the other clusters.

\section{Effect of environmental factors on the bacterial communities}

Effect of seawater physicochemical parameters on the bacterial communities was analyzed. The results show that members of the $\alpha$-Proteobacteria and Flavobacteriia were positively associated with $\% \mathrm{NaCl}$ (Spearman's $r=$ $0.434, P=0.24 ; r=0.63, P=0.06)$ and negatively associated with TSS $(r=-0.68, P=0.04 ; r=-0.76, P=0.01)$. The $\gamma$-Proteobacteria were also positively associated with $\% \mathrm{NaCl}(r=0.39, P=0.30)$ and negatively associated with total P $(r=-0.38, P=0.30)$. The members of $\beta$-Proteobacteria, unidentified Proteobacteria, and Actinobacteria were positively associated with total $\mathrm{N}(r=0.88, P=0.00$; $r=0.88, \quad P=0.00 ; \quad r=0.94, \quad P=0.00)$ and negatively associated with $\% \mathrm{NaCl}(r=-0.73, P=0.02 ; r=-0.63$, 


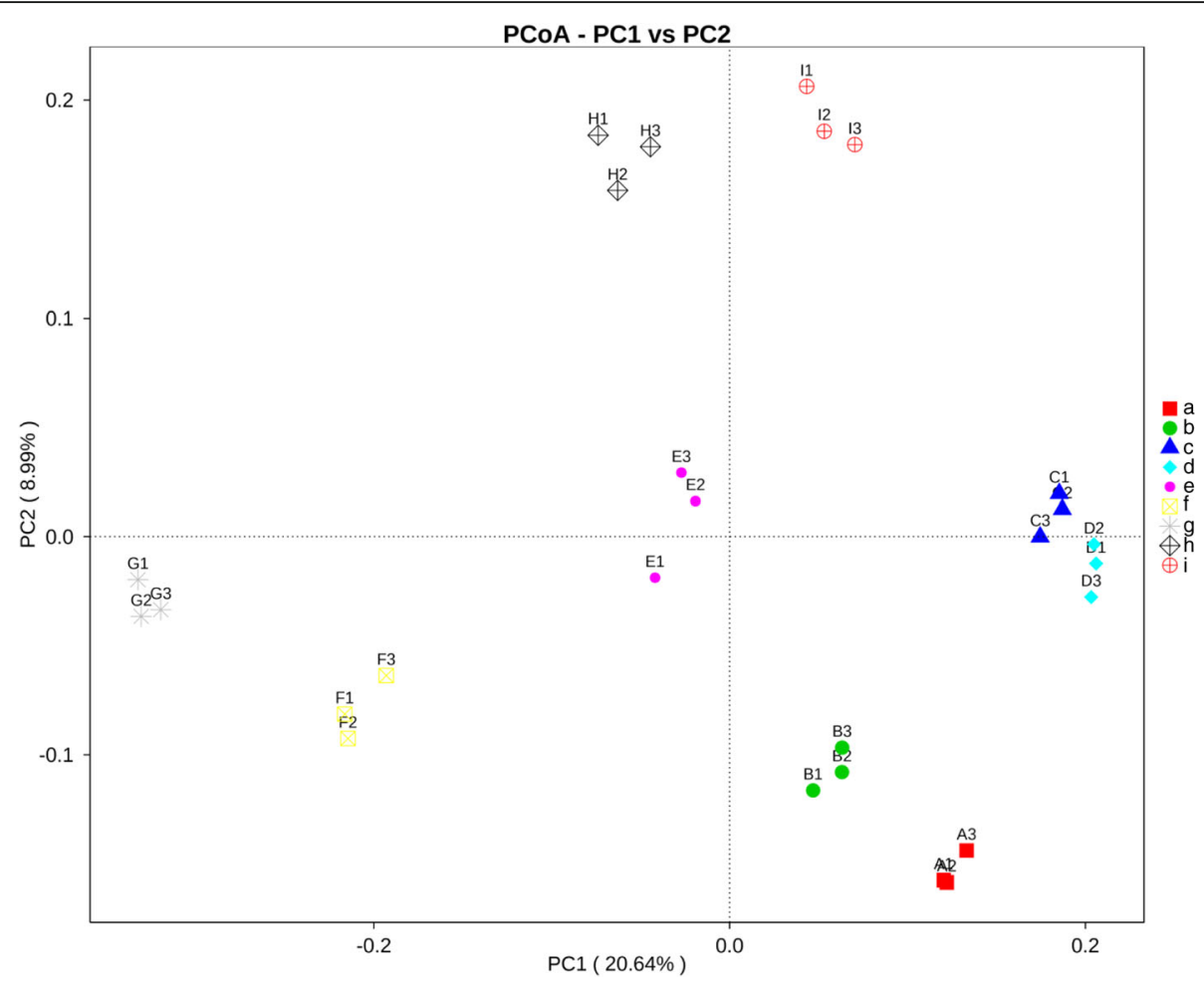

Fig. 4 Principal Coordinate Analysis (PCOA) of species composition similarity by sampling sites. Site a, mangrove forest at Black Sand Beach; b, mangrove forest at Kungkrabaen Bay; $\mathbf{c}$, tourist site at Suanson Beach; $\mathbf{d}$, tourist site at Pattaya Beach; e, aquaculture site at Angsila old market; $\mathbf{f}$, aquaculture site at Donhoylhod; $\mathbf{g}$, aquaculture site at Bangtaboon Bay; $\mathbf{h}$, mangrove forest at Pranburi forest park; i, tourist site at Wanakorn Beach

$P=0.06 ; r=-0.73, P=0.02)$. The Cyanobacteria were positively associated with total $\mathrm{P}(r=0.49, P=0.17)$ and negatively associated with $\mathrm{BOD}_{5}(r=-0.46, P=0.20)$. The Acidimicrobiia were positively associated with total N $(r=$ $0.25, P=0.50)$ and negatively associated with seawater temperature $(r=-0.52, P=0.15)$. The $\delta$-Proteobacteria were positively associated with $\mathrm{BOD}_{5}(r=0.51, P=0.15)$ and negatively associated with total $\mathrm{N}(r=-0.59, P=$ $0.09)$. Moreover, in this study we also found that the numbers of the Marinobacterium, Neptuniibacter, Synechococcus, CandidatusThiobios, hgcI clade (Actinobacteria), and Candidatus Pelagibacter were significantly different when grouped by land use $(P=0.00,0.02,0.02,0.00,0.03$, and 0.00 ). The numbers of Synechococcus and Candidatus Pelagibacter were significantly higher in tourist sites than those in other types of land use, whereas Candidatus Thiobios was only one genus whose number was significantly higher in aquaculture sites than that in other types of land use (Additional file 4: Table S2).

\section{Discussion}

Marine environment is the one of the most extensive habitats for microorganisms, covering more than twothirds of the surface of the earth [20]. Marine bacteria play important roles in energy and matter fluxes in the sea [7]. Normal cell counts of more than $10^{5}$ cells $/ \mathrm{ml}$ in surface seawater support the prediction that the oceans harbor $3.6 \times 10^{29}$ microbial cells with a total cellular carbon content of approximately $3 \times 10^{17} \mathrm{~g}$ [21], thereby an understanding of the marine bacterial distribution and diversity is essential. Although some studies investigated the microbial distribution and diversity with regard to the environmental and geographical conditions [6, 22, 23 ], the marine bacterial distribution and diversity regarding types of land use in the Gulf of Thailand have never been reported. In this study, we first investigated the communities and diversity of bacteria associated with seawater collected from three different types of land use including mangrove forests, tourist sites, and aquaculture sites, over a distance of approximately $769.97 \mathrm{~km}$ along the shores of the Upper Gulf of Thailand. The result shows that run-off water from each type of land use significantly affected the community richness and diversity of marine bacteria. Aquaculture sites contained the highest levels of community richness and diversity, followed by mangrove forests and tourist sites. The maximum richness and diversity in aquaculture sites possibly resulted from aquaculture activities such as feeding that increases the numbers of aquatic animals who are effective feeders promoting high levels of aquatic bacteria 
which are released from their feces and body fluids [24] and addition of readily accessible $C$ source that significantly increases the bacterial biomass [25]. Mangrove forests are complex and dynamic ecosystems that are highly variable in several physicochemical conditions including salinity, flooding, light, temperature, and nutrient, which promote the bacterial diversity. It was reported that mangrove species were the main factors influencing their rhizosphere bacterial communities [26]. The run-off water in tourist sites may come from various sources such as swimmers, trash disposal from tourists, domestic wastewater, and illegal discharge from recreation boats [24]. Hamilton et al. [27] reported that pollutants from anthropogenic-influenced sources conveyed diverse bacteria into beaches and seawater.

Moreover, when determining the effect of environmental factors on the bacterial communities, we found that species richness estimators and OTUs were positively correlated with turbidity. Aquaculture sites had the highest average values of turbidity, TSS, and total N, which were significantly different from those of other types of land use. It can be concluded that a higher seawater turbidity level contributed to higher levels of species richness and OTUs. The positive and negative correlations between bacterial communities in class level and environmental factors were analyzed. The results show that the $\alpha$-Proteobacteria, $\gamma$-Proteobacteria, and Flavobacteriia were positively associated with $\% \mathrm{NaCl}$. The Cyanobacteria were positively associated with total P. The members of $\beta$-Proteobacteria, unidentified Proteobacteria, Acidimicrobiia, and Actinobacteria were positively associated with total $\mathrm{N}$. These results indicate that salinity, total $\mathrm{N}$, and total $\mathrm{P}$ were the ones of the main factors shaping the bacterial communities of nearshore seawater in the Upper Gulf of Thailand, whereas $\mathrm{pH}$ and seawater temperature were not likely to affect the bacterial communities.

Our findings agree with that of Suh et al. [7] who studied seasonal dynamic of marine microbial community in the South Sea of Korea and found that salinity, $\mathrm{N}$, and $\mathrm{P}$ contents contributed substantially to the spatial distribution of bacterial community composition. Salinity showed a marked correlation with the spatial distribution of the Flavobacteriia, while the $\alpha$-Proteobacteria were greatly affected by $\mathrm{N}$ and dissolved oxygen. Likewise, the $\gamma$-Proteobacteria in seawater of Mallorca Island in Spain were positively correlated with salinity [12]. Inorganic nutrients were reported to importantly affect the bacterial community structures of seawater from the Mediterranean Sea, France, under euthrophication conditions [28] and natural seawater across Japan [6].

To more clearly study the similarity among bacterial communities in different sampling sites, UPGMA analysis was applied to display the integration and the relative abundance of each phylum in each site. The result shows that the relative abundance of bacterial phyla in seawater of sites F (aquaculture site at Donhoylhod) and G (aquaculture site at Bangtaboon Bay) was different from that of other sites. This may be affected by the physicochemical factors that shaped the bacterial communities of those two sites which ranked first and second in turbidity, TSS, and total N. Moreover, the proportions of the Proteobacteria, Actinobacteria, Verrucomicrobia, Euryarchaeota, and Deep Sea DHVEG-6 in both sites were more similar to each other than to other sites.

In this study, a total of 4953 OTUs were observed from all samples. Indeed, the amount of the bacterial OTUs was not necessarily correlated with location. The amounts of the bacterial OTUs in samples greatly varied depending on several physicochemical and environmental factors [29, 30]. Other studies revealed that the seawater collected from Gosung Bay (the South Sea of Korea) and Mallorca Island in Spain had only 900 OTUs [7] and 965 OTUs [12], respectively. The considerably more OTUs were observed in marine sediments. Totals of 6039 OTUs, 6059 OTUs, and 5700 to 7600 OTUs were obtained from marine sediments around the Kaichu-Doro Causeway in Okinawa, Japan [31], marine sediments in Yam O Wan Bay, Hong Kong [32], and marine sediments from Jeju Island, South Korea [20], respectively. Moreover, this study found that the proportions of the Proteobacteria were highest in all sampling sites, followed by the Bacteroidetes and Actinobacteria. This result corresponds with that of Suh et al. [7] who reported that the Proteobacteria was the dominant phylum in seawater from Gosung Bay, South Korea, followed by the Bacteroidetes and Actinobacteria. Similarly, most of the bacterial sequence reads in marine sediments from Jeju Island, South Korea, were also associated with the Proteobacteria and Bacteroidetes, followed by the Actinobacteria, Acidobacteria, and Firmicutes [20].

\section{Conclusions}

This is the first report of the bacterial communities and diversity associated with seawater along the Upper Gulf of Thailand that was categorized into three types of land use including mangrove forests, tourist sites, and aquaculture sites. The run-off water from each type of land use significantly affected the community richness and diversity. The highest community richness and diversity were obtained from aquaculture sites, followed by mangrove forests and tourist sites. Turbidity was the most influential parameter affecting the variation in bacterial community composition. Salinity, total N, and P were the ones of the important factors that shaped the bacterial communities in near-shore seawater from the Upper Gulf of Thailand, whereas $\mathrm{pH}$ and seawater temperature less affected the bacterial communities. In addition, the variations of bacterial communities from site-to-site 
were greater than within-site. The Proteobacteria, Bacteroidetes, Actinobacteria, Cyanobacteria, Verrucomicrobia, Euryarchaeota, Planctomycetes, Firmicutes, Deep Sea DHVEG6, and Marinimicrobia were the most and common phyla distributed across the Upper Gulf of Thailand.

\section{Methods \\ Sample collection and determination of seawater parameters}

Seawater was sampled on 10th November and 1st December 2018 at nine sites in seven provinces along the shores of the Upper Gulf of Thailand, over a distance of approximately $769.97 \mathrm{~km}$ (Table 1 and Fig. 1). Sampling sites were selected based on types of land use that were presumably influenced by different run-off conditions. Three sites (A, $\mathrm{B}$, and $\mathrm{H}$ ) were mangrove forests in Black Sand Beach, Kungkrabaen Bay, and Pranburi forest park, respectively. Three tourist sites (C, D, and I) were Suanson Beach, Pattaya Beach, and Wanakorn Beach, respectively. Three aquaculture sites (E, F, and G) were Angsila old market, Donhoylhod, and Bangtaboon Bay, respectively. All sampling sites were in public areas thus no specific permission was required for seawater collection. At each sampling site, near-surface seawater (12 L), approximately $2 \mathrm{~m}$ from the shoreline, was collected in triplicate and stored on ice during within-a-day transit.

Air and seawater temperatures were measured at each sampling site at the time of seawater collection. Seawater samples were analyzed for physicochemical parameters. $\mathrm{pH}$, salinity, and turbidity (in NTU) were measured within $48 \mathrm{~h}$ by using a pH meter (Metrohm $827 \mathrm{pH}$ lab), a hand refractometer (Atago $\mathrm{N}-1 \mathrm{E}$ ), and a turbidimeter $(\mathrm{HACH}$ $2100 \mathrm{P}$ ), respectively. $\mathrm{BOD}_{5}$, total $\mathrm{N}$, total $\mathrm{P}$, and TSS contents were analyzed according to American Public Health Association [33] by using the azide modification method, macro-Kjeldahl method, sulfuric acid-nitric acid digestion method, and drying at $103-105^{\circ} \mathrm{C}$, respectively.

\section{Illumina NGS}

Seawater samples were prefiltered through sterile Whatman no. 2 filter papers to remove suspended particles and the filtrate was subsequently filtered through $0.2 \mu \mathrm{m}$ sterile cellulose nitrate membrane filters (Sartorius, Stedim Biotech., Gottingen, Germany) [4]. DNA was extracted from seawater samples using E.Z.N.A Water DNA kit (Omega Bio-tek, Inc., Norcross, GA, USA), according to the manufacturer's instruction. The V4 variable region of the $16 \mathrm{~S}$ rRNA gene was amplified by using the $515 \mathrm{~F}$ and 806R specific primer set with the barcodes [34, 35]. PCR reactions were carried out with Phusion High-Fidelity PCR Master Mix (NEB, Ipswitch, MA, USA). The PCR products were purified using a Qiagen gel extraction kit (Qiagen, Inc., Valencia, CA, USA). The libraries were generated with TruSeq DNA PCR-Free sample preparation kit (Illumina, Inc., San Diego, CA, USA), and analyzed by HiSeq2500 PE250 sequencing system (Illumina, Inc., San Diego, CA, USA), according to the manufacturer's instructions. Negative controls (sterile water) were carried out through amplification and sequencing. Data was returned as fastq files and deposited in the Sequence Read Archive of the National Center for Biotechnology Information under BioProject accession number PRJNA530863 (SRA: SRP190963).

\section{Data processing and bioinformatic analyses}

Paired-end reads were merged by using the FLASH program (V1.2.7) [36]. Quality filtering on the raw tags was performed to obtain the high-quality clean tags according to the QIIME software (V1.7.0) [37, 38]. The tags were compared with the reference database using the UCHIME algorithm to detect chimera sequences. Chimera sequences were removed to obtain the effective tags $[39,40]$. For OTU clustering and species annotation, sequence analysis was performed with all effective tags by using the Uparse software (V7.0.1001). Sequences with $\geq 97 \%$ similarity were assigned to the same OTUs. The Mothur software (V1.36.1) [41] was used to align each representative sequence against the SSU rRNA database of SILVA [42] for species annotation at each taxonomic level [43]. The phylogenetic relationship of all OTUs derived from representative sequences was analyzed by using the MUSCLE program (V3.8.31) [44].

\section{Statistical analyses}

Alpha diversity, including community richness (Chao1 and ACE estimators), community diversity (Shannon and Simpson indices), and index of sequencing depth (the Good' coverage) as well as rarefaction data were calculated by using the QIIME software (V1.7.0) and displayed by the R software (V2.15.3). PCoA was performed to obtain principal coordinates and visualize complex, multidimensional data, which was then displayed by the WGCNA, stat, and ggplot2 packages in the $\mathrm{R}$ software (V2.15.3). The UPGMA clustering was performed as a type of hierarchical clustering method to interpret the distance matrix using average linkage and conducted by using the QIIME software (V1.7.0). The nonparametic method, ANOSIM, was conducted to determine whether the bacterial community structures significantly differ among groups and within groups. MRPP was calculated with the R software (V2.15.3). AMOVA was performed using the Mothur software (V1.36.1). Seawater parameters, alpha diversity indices, and physicochemical parameters of each type of land use were subjected to an analysis of variance (ANOVA) using Tukey's test. Spearman rank correlation was used to analyze the effect of seawater physicochemical parameters on the bacterial communities. ANOVA and Spearman rank correlations 
were performed with the SPSS statistical software (V19.0) (IBM Corp., Chicago, IL, USA). All statistical analyses were evaluated at $\alpha=0.05$.

\section{Supplementary information}

Supplementary information accompanies this paper at https://doi.org/10. 1186/s12866-020-1701-6.

Additional file 1: Figure S1. Rarefaction curves of observed species number from three samplings of each sampling site. Site A, mangrove forest at Black Sand Beach; B, mangrove forest at Kungkrabaen Bay; C, tourist site at Suanson Beach; D, tourist site at Pattaya Beach; E, aquaculture site at Angsila old market; $F$, aquaculture site at Donhoylhod; $\mathrm{G}$, aquaculture site at Bangtaboon Bay; $\mathrm{H}$, mangrove forest at Pranburi forest park; I, tourist site at Wanakorn Beach

Additional file 2: Figure S2. OTUs flower analysis of sampling sites. Additional file 3: Table S1. Top ten most abundant genera present in each site. All sites were sampled in triplicate $(n=3)$. *Values are the means from three samplings \pm standard deviations. ${ }^{* *}$ Values with the same letters within a column are not significantly different according to Tukey's test.

Additional file 4: Table S2. Top ten most abundant genera present in each type of land use. *Values are the means of three samplings from each location \pm standard deviations. ${ }^{*}$ Values with the same letters within a column are not significantly different according to Tukey's test. *** $p$-values $<0.05$ are considered significant.

\section{Abbreviations}

ACE: Abundance-based coverage estimator; AMOVA: Analysis of molecular variance; ANOSIM: Analysis of similarity; ANOVA: Analysis of variance; $\mathrm{BOD}_{5}$ : Five-day biochemical oxygen demand; MRPP: Multi-response permutation procedure; NGS: Next-generation sequencing; NTU: Nephelometric turbidity unit; OTU: Operational taxonomic unit; PCoA: Principal coordinate analysis; TSS: Total suspended solid; UPGMA: Unweighted-pair group method with arithmetic mean

\section{Acknowledgements}

Not applicable.

\section{Authors' contributions}

PN and NP contributed equally to this article. NP conceived and designed this study. PN and NP performed the experiments, analyzed the data and wrote the manuscript. All authors have read and approved the manuscript.

\section{Authors' information}

PN is an assistant professor in the Department of Microbiology, Faculty of Liberal Arts and Science, Kasetsart University, Thailand. He received a scholarship from the government of Thailand to complete his Ph.D. in applied microbiology at Chiang Mai University. He had attended GÖttingen University, Germany, and Tokyo University, Japan, as a collaborative Ph.D. student. His research interests include actinomycetes, secondary metabolites from bacteria, microbial ecology as well as environmental science. NP is an associate professor in the Department of Microbiology, Faculty of Science, Silpakorn University, Thailand. She received a scholarship from the government of Thailand to complete her Ph.D. in biotechnology at Suranaree University of Technology. She had attended the university of Minnesota, USA, as a collaborative Ph.D. student and a visiting researcher. She was a postdoctoral fellow at the university of Wisconsin-Madison, USA Her research interests include microbial ecology, molecular genetics of bac teria, plant growth-promoting bacteria as well as environmental science.

\section{Funding}

This study was financially supported by the Thailand Research Fund (TRF) under grant contract no. DBG6180026. The funder had no role in the experimental design, sample collection, data analysis and interpretation or manuscript preparation.

\section{Availability of data and materials}

All data generated or analyzed during this study has been included in this published article. Sequence data has been deposited in the Sequence Read Archive of the National Center for Biotechnology Information under BioProject accession number PRJNA530863 (SRA: SRP190963).

\section{Ethics approval and consent to participate}

Not applicable.

\section{Consent for publication}

Not applicable.

\section{Competing interests}

The authors declare no competing interests.

\section{Author details}

${ }^{1}$ Department of Microbiology, Faculty of Liberal Arts and Science, Kasetsart University, Nakhon Pathom, Thailand. ${ }^{2}$ Department of Microbiology, Faculty of Science, Silpakorn University, Nakhon Pathom, Thailand.

Received: 16 September 2019 Accepted: 9 January 2020

Published online: 23 January 2020

\section{References}

1. Chancham C, Waewsak J, Gagnon Y. Wind resource assessment in the northern gulf of Thailand using atmospheric modeling and climatic database. Int J Renew Energy. 2016;11:9-15.

2. Department of Marine and Coastal Resources, Thailand. The Oceanography of the Gulf of Thailand.2013. https://km.dmcr.go.th/en/c_51/d_1132. Accessed 15 July 2019

3. Pollution Control Department, Thailand. Resource map and land utilization of the coastal areas of the Upper Gulf of Thailand. 1st ed. Bangkok: BTS Press Co., Ltd; 2012

4. Staley C, Pongsilp N, Nimnoi P, Kaiser T, Sadowsky MJ. Influence of physicochemical factors on bacterial communities along the lower Mekong River assessed by Illumina next-generation sequencing. Water Air Soil Pollut. 2018;229:321

5. Poli A, Finore I, Romano I, Gioiello A, Lama L, Nicolaus B. Microbial diversity in extreme marine habitats and their biomolecules. Microorganisms. 2017:5:25.

6. Terahara T, Yamada K, Nakayama J, Igarashi Y, Kobayashi T, Imada C. Bacterial community structures of deep-sea water investigated by molecular biological techniques. Gene. 2016:576:696-700.

7. Suh SS, Park M, Hwang J, Kil EJ, Jung SW, Lee S, et al. Seasonal dynamics of marine microbial community in the South Sea of Korea. PLoS One. 2015;10: e0131633

8. Yergeau E, Michel C, Tremblay J, Niemi A, King TL, Wyglinski J, et al. Metagenomic survey of the taxonomic and functional microbial communities of seawater and sea ice from the Canadian Arctic. Sci Rep. 2017:7:42242.

9. Campbell A, Marzinelli EM, Gelber J, Steinberg PD. Spatial variability of microbial assemblages associated with a dominant habitat-forming seaweed. Front Microbiol. 2015:6:230

10. Walsh EA, Kirkpatrick JB, Rutherford SD, Smith DC, Sogin M, D'Hondt S. Bacterial diversity and community composition from seasurface to subseafloor. ISME J. 2016;10:979-89.

11. Baltar F, Palovaara J, Unrein F, Catala P, Horňák K, Simek K et al. Marine bacterial community structure resilience to changes in protist predation under phytoplankton bloom conditions. ISME J. 2016;10:568-81.

12. Héry M, Volant A, Garing C, Luquot L, Elbaz Poulichet F, Gouze P. Diversity and geochemical structuring of bacterial communities along a salinity gradient in a carbonate aquifer subject to seawater intrusion. FEMS Microbiol Ecol. 2014;90:922-34.

13. Won NI, Kim KH, Kang JH, Park SR, Lee HJ. Exploring the impacts of anthropogenic disturbance on seawater and sediment microbial communities in Korean coastal waters using metagenomics analysis. Int J Environ Res Public Health. 2017;14:130.

14. Salipante SJ, Kawashima T, Rosenthal C, Hoogestraat DR, Cummings LA Sengupta DJ, et al. Performance comparison of Illumina and ion torrent next generation sequencing platforms for 165 rRNA-based bacterial community profiling. Appl Environ Microbiol. 2014;80:7583-91. 
15. Cao Y, Fanning S, Proos S, Jordan K, Srikumar S. A review on the applications of next generation sequencing technologies as applied to food-related microbiome studies. Front Microbiol. 2017;8:1829.

16. Mason OU, Hazen TC, Borglin S, Chain PS, Dubinsky EA, Fortney JL, et al. Metagenome, metatranscriptome and single-cell sequencing reveal microbial response to Deepwater horizon oil spill. ISME J. 2012;6:1715-27.

17. Rivers AR, Sharma S, Tringe SG, Martin J, Joye SB, Moran MA. Transcriptional response of bathypelagic marine bacterioplankton to the Deepwater horizon oil spill. ISME J. 2013;7:2315-29.

18. Arumugam R, Chan XY, Yin WF, Choo SW, Chan KG. Metagenomic analysis of microbial diversity of tropical sea water of Georgetown coast, Malaysia. Life Sci. 2013;10:2392-6.

19. Lee SY, Eom YB. Analysis of microbial composition associated with freshwater and seawater. Biomed Sci Lett. 2016;22:150-9.

20. Choi H, Koh HW, Kim H, Chae JC, Park SJ. Microbial community composition in the marine sediments of Jeju island: next-generation sequencing surveys. J Microbiol Biotechnol. 2016:26:883-90.

21. Whitman WB, Coleman DC, Wiebe WJ. Prokaryotes: the unseen majority. Proc Natl Acad Sci USA. 1998;98:6578-83.

22. Kai W, Peisheng Y, Rui M, Wenwen J, Zongze S. Diversity of culturable bacteria in deep-sea water from the South Atlantic Ocean. Bioengineered. 2017:8:572-84.

23. Cleary DFR, Polónia ARM, Becking LE, de NJ V, Purwanto GH, et al. compositional analysis of bacterial communities in seawater, sediment, and sponges in the Misool coral reef system, Indonesia. Mar Biodivers. 2018:48:1889-901.

24. Karbasdehi VN, Dobaradaran S, Nabipour I, Ostovar A, Arfaeinia H, Vazirizadeh A, et al. Indicator bacteria community in seawater and coastal sediment: the Persian Gulf as a case. J Environ Health Sci Eng. 2017;15:6.

25. Emerencio M, Gaxiola G, Cuzon G. Biofloc technology (BFT): a review for aquaculture industry and animal food industry. In: Matovic MD, editor. Biomass now- cultivation and utilization. London: Intech Open Limited; 2013. p. 301-28.

26. Wu P, Xiong $X, X u Z$, Lu C, Cheng H, Lyu X, et al. Bacterial communities in the rhizospheres of three mangrove tree species from Beilun estuary, China. PLoS ONE. 2016;11:e0164082.

27. Hamilton MJ, Hadi AZ, Griffith JF, Ishii S, Sadowsky MJ. Large scale analysis of virulence genes in Escherichia coli strains isolated from Avalon bay CA. Water Res. 2010;44:5463-73.

28. Lebaron P, Servais P, Troussellier M, Courties C, Vives-Rego J, Muyzer G, et al. Changes in bacterial community structure in sea-water mesocosms differing in their nutrient status. Aquat Microb Ecol. 1999;19:255-67.

29. Zinger L, Amaral-Zettler LA, Fuhrman JA, Horner-Devine MC, Huse SM, Horner-Devine C, et al. Global patterns of bacterial beta-diversity in seafloor and seawater ecosystems. PLoS One. 2011;6:e24570.

30. Li YY, Chen XH, Xie ZX, Li DX, Wu PF, Kong LF, et al. Bacterial diversity and nitrogen utilization strategies in the upper layer of the northwestern Pacific Ocean. Front Microbiol. 2018;9:797.

31. Soliman T, Reimer JD, Yang SY, Villar-Briones A, Roy MC, Jenke-Kodama H. Diversity of microbial communities and quantitative chemodiversity in layers of marine sediment cores from a causeway (Kaichu-Doro) in Okinawa Island, Japan. Front Microbiol. 2017:8:2451

32. Wang Y, Sheng HF, He Y, Wu JY, Jiang YX, Tam NFY, et al. Comparison of the levels of bacterial diversity in freshwater, intertidal wetland, and marine sediments by using millions of illumina tags. Appl Environ Microbiol. 2012;78:8264-71.

33. American Public Health Association (APHA). Standard methods for the examination of water and wastewater. 22nd. Washington, DC: American Public Health Association;2012.

34. Apprill A, McNally S, Parsons R, Weber L. Minor revision to V4 region SSU rRNA 806R gene primer greatly increases detection of SAR11 bacterioplankton. Aquat Microb Ecol. 2015;75:129-37.

35. Parada AE, Needham DM, Fuhrman JA. Every base matters: assessing small subunit rRNA primers for marine microbiomes with mock communities, time series and global field samples. Environ Microbiol. 2016;18:1403-14.

36. Magoč T, Salzberg SL. FLASH: fast length adjustment of short reads to improve genome assemblies. Bioinformatics. 2011;27:2957-63.

37. Caporaso JG, Kuczynski J, Stombaugh J, Bittinger K, Bushman FD, Costello EK, et al. QIIME allows analysis of high-throughput community sequencing data. Nat Methods. 2010;7:335-6.

38. Bokulich NA, Subramanian S, Faith JJ, Gevers D, Gordon Jl, Knight R, et al. Quality-filtering vastly improves diversity estimates from Illumina amplicon sequencing. Nat Methods. 2013;10:57-9.
39. Edgar RC, Haas BJ, Clemente JC, Quince C, Knight R. UCHIME improves sensitivity and speed of chimera detection. Bioinformatics. 2011;27:2194-200.

40. Haas BJ, Gevers D, Earl AM, Feldgarden M, Ward DV, Giannoukos G, et al. Chimeric 165 rRNA sequence formation and detection in Sanger and 454pyrosequenced PCR amplicons. Genome Res. 2011;21:494-504.

41. Schloss PD, Westcott SL, Ryabin T, Hall JR, Hartmann M, Hollister EB, et al. Introducing mothur: open-source, platform-independent, communitysupported software for describing and comparing microbial communities. Appl Environ Microbiol. 2009;75:7537-41.

42. Wang Q, Garrity GM, Tiedje JM, Cole JR. Naïve Bayesian classifier for rapid assignment of rRNA sequences into the new bacterial taxonomy. Appl Environ Microbiol. 2007;73:5261-7.

43. Quast C, Pruesse E, Yilmaz P, Gerken J, Schweer T, Yaza P, et al. The SILVA ribosomal RNA gene database project: improved data processing and webbased tools. Nucleic Acids Res. 2013;41:D590-6.

44. Edgar RC. MUSCLE: multiple sequence alignment with high accuracy and high throughput. Nucleic Acids Res. 2004;32:1792-7.

\section{Publisher's Note}

Springer Nature remains neutral with regard to jurisdictional claims in published maps and institutional affiliations.

Ready to submit your research? Choose BMC and benefit from:

- fast, convenient online submission

- thorough peer review by experienced researchers in your field

- rapid publication on acceptance

- support for research data, including large and complex data types

- gold Open Access which fosters wider collaboration and increased citations

- maximum visibility for your research: over $100 \mathrm{M}$ website views per year

At $\mathrm{BMC}$, research is always in progress.

Learn more biomedcentral.com/submissions 